\title{
Protective effect of uric acid against 6-OHDA- induced injury in SH-SY5Y cells
}

Tingting Huang ${ }^{1,2}$, Li Gong ${ }^{1,2}$, Weifeng Luo ${ }^{1,2^{*}}$, Lifang Hu², Chunfeng Liu ${ }^{1,2}$

From 2011 International Conference on Molecular Neurodegeneration

Shanghai, China. 22-24 September 2011

\section{Objective}

To investigate the effect of uric acid (UA) on 6-hydroxydopamine (6-OHDA) -induced injury in SH-SY5Y cells.

\section{Methods}

The cell viability was measured by the MTT reduction assay. The cell apoptosis was assessed by Hoechst 33342 staining with fluorescence microscopy. The phophorylation of Akt and GSK-3ß(ser9) was determined by Western blot analysis.

\section{Results}

Treatment with 6-OHDA at $50 \mu \mathrm{M}$ for $12 \mathrm{~h}$ significantly decreased the viability of SH-SY5Y cells. Pretreatment with UA $(200-400 \mu \mathrm{M}, 0.5 \mathrm{~h})$ prior to 6-OHDA treatment markedly increased the cell viability of SH-SY5Y cells, as compared to that of 6-OHDA-treated group. The beneficial effects of UA against 6-OHDA-induced apoptosis were also confirmed by Hoechst 33342 staining assay. Moreover, 6-OHDA decreased the Akt activity and increased the GSK-3 $\beta$ activity, which could be blocked by UA $(200-400 \mu \mathrm{M})$ pretreatment.

\section{Conclusions}

These data suggest that 6-OHDA-induced cell injury was attenuated by UA. The underlying mechanisms may involve the up-regulation of Akt and the reduction of

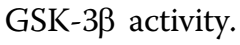

\section{Acknowledgements}

Contract grant sponsor: The work was supported by the Suzhou Foundation for Development of Science, Technology (200815404), Jiangsu Ordinary University Science Research Project (08KJB320012) and Natural Science Foundation of Jiangsu Province, China (BK2010229).

\footnotetext{
*Correspondence: Iwfwxx@126.com

'The Department of Neurology, Second Affiliated Hospital of Soochow University, Suzhou,China

Full list of author information is available at the end of the article
}

\section{Author details}

${ }^{1}$ The Department of Neurology, Second Affiliated Hospital of Soochow University, Suzhou,China. ${ }^{2}$ The Institute of Neuroscience of Soochow University, Suzhou, China.

Published: 7 February 2012

doi:10.1186/1750-1326-7-S1-S12

Cite this article as: Huang et al:: Protective effect of uric acid against 6OHDA-induced injury in SH-SY5Y cells. Molecular Neurodegeneration 2012 7(Suppl 1):S12.
Submit your next manuscript to BioMed Central and take full advantage of:

- Convenient online submission

- Thorough peer review

- No space constraints or color figure charges

- Immediate publication on acceptance

- Inclusion in PubMed, CAS, Scopus and Google Scholar

- Research which is freely available for redistribution
C Biomed Central 